\title{
ANALISIS KESEJAHTERAAN PSIKOLOGIS KARYAWAN DAN KUALITAS INTERAKSI BAWAHAN BERDASARKAN KEPRIBADIAN ATASAN
}

\author{
Nuri Sadida ${ }^{1}$, Nurindah Fitria ${ }^{2}$ \\ ${ }^{1,2}$ Fakultas Psikologi, Universitas YARSI. \\ Jl. Letjend Soeprapto Kav. 13, Cempaka Putih, Jakarta Pusat. 10510 \\ ${ }^{1}$ nuri.sadida@yarsi.ac.id
}

\begin{abstract}
This research background was the low indicator of employee well-being (EWB) in Jakarta that derived from several employee surveys. One factor that has significant influence to EWB is management leadership. The aims of this research are to test the correlation between leader-member exchange and employee well-being, and to test correlation between leader's personality type and leader-member exchange. Participants involved in this study are 72 employees, that was taken using accidental sampling. This research adopted LMX7 scale to measure the leader-member exchange, EWB tool based on Juniper theory (2010) to measure employee well-being, and DISC personality to measure personality type. Result showed there is a significant correlation between leader-member exchange and employee well being, and there is correlation between leader's personality type, specifically type C and $\mathrm{S}$ with leader-member exchange. This result can be used for Human Resources Management to consider employee with type $\mathrm{C}$ and $\mathrm{S}$ to fill position as middle level manager.
\end{abstract}

Keywords: employee well-being, leader-member exchange, leader's personality type

\begin{abstract}
Abstrak
Penelitian ini dilatarbelakangi rendahnya kesejahteraan psikologis karyawan di Jakarta. Salah satu faktor yang dapat meningkatkan kesejahteraan psikologis karyawan adalah kepemimpinan perusahaan. Tujuan dari penelitian ini adalah untuk melihat hubungan antara kualitas interaksi atasan-bawahan dan kesejahteraan psikologis karyawan, serta untuk melihat hubungan antara tipe kepribadian atasan dengan kualitas interaksi atasanbawahan. Subjek pada penelitian ini sejumlah 72 orang karyawan, yang diperoleh dengan teknik accidental sampling. Alat pengumpulan data adalah kuesioner Leader Member Exchange (LMX) untuk melihat kualitas interaksi atasan bawahan dan kuesioner DISC untuk melihat tipe kepribadian karyawan, yang semuanya sudah diadaptasikan ke dalam konteks Indonesia. Untuk mengukur kesejahteraan psikologis karyawan, peneliti mengonstruksi alat ukur baru menggunakan dimensi kesejahteraan psikologis karyawan. Hasil penelitian menunjukkan terdapat hubungan yang signifikan antara kualitas interaksi
\end{abstract}


atasan bawahan dengan tingkat kesejahteraan psikologis karyawan,. Tipe kepribadian atasan, khususnya tipe dominan $\mathrm{C}$ dan $\mathrm{S}$, memiliki hubungan dengan kualitas hubungan atasan bawahan. Hasil penelitian ini dapat digunakan oleh praktisi SDM di perusahaan untuk mempertimbangkan karyawan dengan tipe $\mathrm{C}$ dan $\mathrm{S}$ untuk dipromosikan sebagai supervisor atau manajer level menengah.

Kata kunci: kesejahteraan psikologis karyawan, kualitas interaksi atasan bawahan, tipe kepribadian atasan

\section{Pendahuluan}

Kesejahteraan psikologis karyawan menjadi salah satu isu yang semakin mencuat di kalangan karyawan yang bekerja di Jakarta. Survei yang dilakukan laporan Accenture pada tahun 2012 (dalam Lestari, 2017), hanya ada 18\% karyawan yang merasakan puas dan bahagia dengan pekerjaannya. Sementara The JakartaPost (2012) melaporkan hasil studi Nielsen yang menyebutkan bahwa perhatian karyawan saat ini semakin meningkat akan keseimbangan hidup antara pekerjaan dan keluarga, seiring semakin meningkatnya stres akibat beban kerja. Hal ini menunjukkan bahwa perusahaan perlu memberikan perhatian lebih untuk meningkatkan kesejahteraan psikologis karyawan di tempat kerja agar produktivitas dan kinerja karyawan tidak terganggu.

Salah satu sumber daya yang mendukung pekerjaan seorang karyawan adalah hubungan yang baik dengan rekan kerja, terutama pemimpin atau atasannya. Atasan memiliki peran dalam meningkatkan kesejahteraan psikologis bawahan dengan membuat tempat kerja menjadi sehat, tidak mengabaikan pengawasan, memotivasi karyawan, serta mencerminkan nilai-nilai pekerjaan yang penting bagi karyawan (Badeni, 2013). Faktor lain yang dapa mempengaruhi kinerja bawahan adalah kualitas interaksi atasan-bawahan seperti cara komunikasi atasan-bawahan (Tanuwijaya \& Kurniadi, 2007)

Kualitas interaksi atasan bawahan diistilahkan dengan leader-member exchange (LMX) yaitu suatu hubungan pertukaran interpersonal antara bawahan dan pemimpinnya (Graen, dalam Ping \& Yue, 2010). Graen (1976) memiliki hipotesis bahwa pada situasi, konteks, dan ketika berhadapan oleh orang tertentu, seorang manajer akan mengubah perannya. Teori LMX menjelaskan bahwa karyawan dalam satu kelompok departemen/ divisi terbagi menjadi beberapa sub kelompok, dimana anggota salah satu kelompok ini memiliki hubungan khusus dengan atasannya dikarenakan bawahan menunjukkan respon dan tanggung jawab yang diharapkan oleh atasan. Akibatnya, atasan memberikan dukungan lebih untuk pekerjaan bawahan, seperti memberikan informasi yang lebih banyak, memberikan tugas yang menantang, atau otonomi dalam bekerja. Kelompok ini disebut "in-group" atau kelompok internal. Hubungan seperti ini, ditandai dengan kesamaan pandangan, saling menghargai dan mempercayai, serta saling mempengaruhi satu sama lain. Atasan umumnya menghabiskan waktu lebih banyak dengan kelompok internal ini, dan karenanya kelompok internal umumnya merasakan kepuasan kerja yang lebih tinggi

dikarenakan perannya di dalam kelompok. Kelompok internal juga diharapkan lebih loyal dan komit dengan atasan ( Graen \& Uhl-Bien, 1995) 
Bawahan yang tidak menunjukkan sikap kerja yang memuaskan atasan, maka atasan akan memperlakukan bawahan dalam kategori "out-group". Bawahan yang berada dalam kategori "out-group" umumnya mengalami interaksi yang formal dengan atasannya (Maslyn \& Uhl-Bien, 2001). Kelompok"out-group" atau kelompok eksternal, biasanya kurang termotivasi dalam pekerjaan dan tidak memiliki kompetensi khusus (SIOP, 1998).

Berdasarkan penjelasan tersebut, dapat terlihat bahwa kualitas interaksi atasanbawahan dipengaruhi oleh proses komunikasi yang berkembang antara atasan dan bawahan. Proses komunikasi ini juga dipengaruhi oleh gaya komunikasi baik atasan maupun bawahan. Gaya komunikasi yang ditampilkan seseorang dapat dilihat melalui tipe kepribadiannya, yang berdasarkan kategori dari Marston (1928), tipe kepribadian seseorang terbagi menjadi Dominance (D), Inducement (I), Submission (S), dan Conscientious (C).

Setiap dari tipe kepribadian tersebut menampilkan gaya komunikasi yang berbeda, yang dihasilkan dari persepsi seseorang akan hubungannya dengan lingkungannya. Seseorang dengan tipe yang Dominance (D) memiliki dorongan besar untuk mengontrol dan meraih tujuan/target. Intensi dari tipe kepribadian ini adalah untuk mengatasi permasalahan (to overcome). Sementara seseorang tipe Influence (I), miliki dorongan untuk mempengaruhi, berekspresi, dan didengarkan. Intensi dari tipe kepribadian ini adalah mengajak orang lain (to persuade). Individu dengan tipe Steadiness (S), adalah individu yang memiliki dorongan untuk menjadi stabil dan konsisten. Intensi dari tipe kepribadian ini adalah mendukung (to support). Terakhir, individu tipe Conscientious (C), adalah individu yang memiliki dorongan untuk menjadi benar, pasti, dan aman.

Tipe kepribadian ini diukur oleh skala DISC. Alat ukur DISC dalam dunia industri, terutama di perusahaan-perusahaan di Jakarta, banyak digunakan untuk kegiatan penilaian calon karyawan dan dalam pengembangan karyawan. Penggunaan alat ukur DISC sudah sangat banyak digunakan dunia industri, namun penelitian tentang tipe kepribadian seseorang yang menggunakan alat ukur DISC dengan partisipan karyawan belum banyak diteliti di Indonesia. Beberapa penelitian di Indonesia yang menggunakan alat ukur DISC dilakukan lebih banyak dilakukan dengan melibatkan partisipan mahasiswa (Goni, Opod, \& David, 2016; Utami \& Pratitis, 2013; Nastiti, 2015), dan tidak banyak penelitian bidang psikologi yang melibatkan partisipan karyawan.

Penjelasan inilah yang mendasari asumsi bahwa terdapat tipe kepribadian tertentu dari atasan yang dapat mempengaruhi tingkat kualitas interaksi atasan dan bawahan, yang kemudian dapat diduga mempengaruhi kesejahteraan psikologis karyawan di tempat kerja. Berdasarkan permasalahan tersebut, maka hipotesis dalam penelitian ini adalah terdapat hubungan antara tipe kepribadian atasan dengan kualitas interaksi atasan-bawahan serta terdapat hubungan antara kualitas interaksi atasan-bawahan dan kesejahteraan psikologis karyawan.

Penelitian kesejahteraan psikologis karyawan di tempat kerja (employee well being) pada umumnya menilai kesejahteraan psikologis berdasarkan karakteristik pekerjaan karyawan. Dua kerangka teori yang sudah populer untuk mengukur kesejahteraan psikologis yaitu Model Job-Demand Control (JDC) dan model Effort-Reward Imbalance (ERI). Model JDC dicetuskan oleh Karasek (1979), dimana Karasek menjelaskan bahwa tekanan mental yang dialami dalam pekerjaan adalah hasil dari interaksi antara tuntutan pekerjaan dan kemampuan menentukan arah atau keputusan dalam pekerjaan yang dialami seorang karyawan. Model ERI menjelaskan kesejahteraan psikologis karyawan adalah 
keseimbangan antara besaran usaha yang dikeluarkan oleh karyawan dengan imbalan yang didapatkan karyawan tersebut. Kegagalan mendapatkan keseimbangan antara kedua hal tersebut yang menyebabkan rendahnya kesejahteraan psikologis karyawan (Siegrist, 2012).

Penelitian - penelitian terbaru tentang employee well-being (EWB) menggambarkan karakteristik lingkungan kerja yang lebih luas dapat mempengaruhi EWB. Seperti penelitian yang dilakukan Orsila, Luukkaala, Luukkaala, Manka, dan Nygard (2011), dimana dalam penelitiannya yang bertujuan untuk mengembangkan alat ukur versi ringkas untuk mengukur kesejahteraan psikologis karyawan, diuji 27 faktor yang sekiranya mempengaruhi kesejahteraan psikologis karyawan, namun dalam penelitian yang sama, disebutkan bahwa keterbatasan penelitian tersebut yaitu bahwa penelitian berfokus pada faktor organisasional dan faktor intrinsik seseorang, namun kurang mengevaluasi faktor lingkungan kerja.

Penelitian lain yang dilakukan Juniper (2010) juga meneliti dimensi-dimensi yang mempengaruhi kesejahteraan psikologis karyawan pada berbagai konteks pekerjaan. Hasil dari berbagai penelitian yang dilakukan Juniper tersebut menghasilkan tujuh dimensi yang memiliki konsistensi antar aitem dan validitas alat ukur yang baik. Berdasarkan hal tersebut peneliti memutuskan untuk menggunakan pendekatan kesejahteraan psikologis karyawan ini. Juniper (2010) menggunakan definisi kesejahteraan psikologis karyawan sebagai bagian dari kesejahteraan menyeluruh karyawan yang sangat ditentukan oleh faktor pekerjaan dan dapat dipengaruhi oleh intervensi dari tempat kerja karyawan. Tujuh dimensi menurut Juniper yang mempengaruhi kesejahteraan psikologis karyawan di tempat kerja yaitu Home Work Interface (HWI), Job (JOB), Physical Health (PHY), Relationships (REL), Psychological Health (PSY), Advancement (ADV), Facilities (FAC). Penjelasan dari masing-masing dimensi tersebut adalah sebagai berikut : Home Work Interface (HWI) menjelaskan bagaimana pekerjaan karyawan memberikan dampak pada kehidupan karyawan di luar pekerjaannya yang mempengaruhi kesejahteraan pekerja; Job (JOB), menjelaskan bagaimana suatu aspek tertentu dalam pekerjaan mempengaruhi kesejahteraan karyawan, seperti: waktu kerja, beban kerja, gaji dan budaya tempat kerja; Physical Health (PHY), menjelaskan bagaimana pekerjaan seorang karyawan mempengaruhi kesehatan fisik karyawan tersebut; Relationships (REL) menjelaskan interaksi atau hubungan antara karyawan dengan manajer dan rekan kerja atau para koleganya; Psychological Health (PSY), menjelaskan bagaimana pekerjaan karyawan mempengaruhi kesehatan psikologis karyawan. Seperti: stress, penurunan motivasi bekerja dan burn out;Advancement (ADV) menjelaskan bagaimana kebutuhan pelatihan dan pengembangan kerja serta promosi pada karyawan perusahaan; Facilities (FAC) menjelaskan gambaran kebutuhan lingkungan tempat bekerja karyawan seperti akomodasi dan fasilitas di tempat kerja.

\section{Metode Penelitian}

Penelitian ini menggunakan pendekatan kuantitatif. Adapun rancangan penelitian ditampilkan dalam gambar 1. 


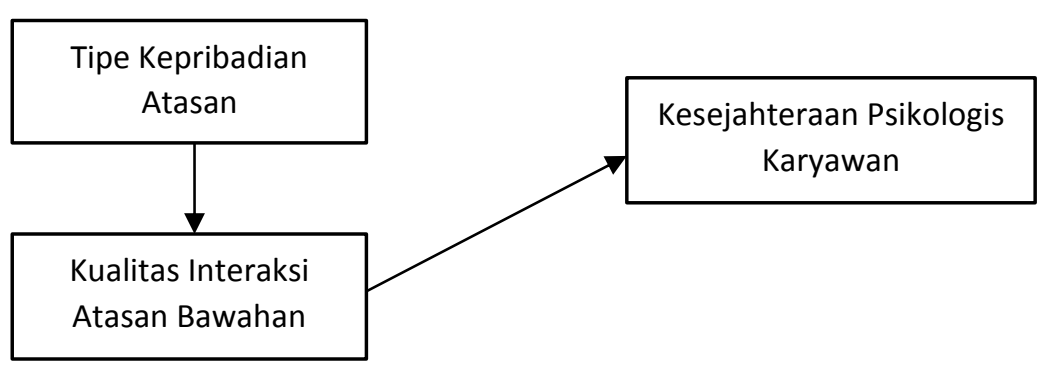

Gambar 1 Rancangan Penelitian

Populasi yang dituju dalam penelitian ini adalah karyawan yang bekerja di Jakarta. Partisipan diambil dengan teknik accidental sampling, dan diperoleh 72 partisipan. Tim peneliti meminta kesediaan kepada karyawan perusahaan untuk berpartisipasi dalam penelitian ini melalui departemen HRD dari setiap perusahaan. Setelah izin didapatkan, maka peneliti melakukan pengambilan data pada karyawan perusahaan.

Alat ukur yang digunakan dalam penelitian ini yaitu:

1. DISC, berupa pengukuran profil kepribadian. Kepribadian yang diukur terdiri dari 4 tipe kepribadian, yaitu Dominant (D), Influence (I), Steady (S), dan Conscientious (C). Alat ukur ini memperlihatkan tipe kepribadian dominan yang dimiliki setiap individu, bisa salah satu ataupun interaksi antara dua atau tiga diantaranya. Alat ukur DISC terdiri dari 24 aitem dimana responden diminta untuk memilih satu pernyataan yang paling menggambarkan dirinya dan satu pernyataan yang paling tidak menggambarkan dirinya dari empat pilihan jawaban yang terdapat pada tiap item. Pada penelitian ini peneliti hanya mengelompokkan menjadi empat kelompok tipe kepribadian yang berbeda, yaitu tipe kepribadian dominan yang tampak dari tiap individu, yaitu D, I, S, atau $\mathrm{C}$.

2. LMX7 (Leader-Member Exchange) dari Liden dan Maslyn (1998) adalah alat ukur yang digunakan untuk mengukur interaksi atau hubungan antara atasan dan bawahan. Jumlah aitemnya sebanyak 11 aitem, dimana pernyataan pada skala ini merupakan aitem favorable. Skala ini terdiri dari 6 pilihan jawaban, yaitu $1=$ sangat tidak setuju, 2 = tidak setuju, 3 = hampir tidak setuju, $4=$ hampir setuju, $5=$ setuju, $6=$ sangat setuju. Semakin tinggi skor rata-rata yang diperoleh individu maka menunjukkan kualitas interaksi yang semakin baik dengan atasan. Menurut Liden dan Maslyn (1998) terdapat 4 dimensi yang diukur dalam skala ini, yaitu: Affect (afek), yaitu interaksi timbal balik yang dimiliki antara atasan dengan bawahan dalam suatu hubungan yang didasarkan terutama pada ketertarikan secara pribadi dari pada pekerjaan atau nilai-nilai (misal: Persahabatan); Loyalty ( Loyalitas), adalah ungkapan dukungan terhadap tujuan dan karakter personal dari anggota hubungan atasan-bawahan (atasan loyal terhadap bawahan, bawahan loyal terhadap atasan); Contribution (Kontribusi), adalah persepsi dari tingkat aktivitas orientasi kerja setiap anggota memiliki arah atau tujuan bersama dalam hubungan atasan-bawahan;Professional Respect ( Respek terhadap profesi), adalah persepsi pada tingkat dimana setiap anggota dalam dyad membuat suatu reputasi, baik itu di dalam atau di luar organisasi. 
3. Alat ukur kesejahteraan psikologis karyawan diadaptasi dari alat ukur Work Related Well-Being (WRWB) dari Juniper (2010) yang mengukur tujuh dimensi yang mempengaruhi kesejahteraan psikologis karyawan di tempat kerja, yaitu Home Work Interface (HWI), Job (JOB), Physical Health (PHY), Relationships (REL), Psychological Health (PSY), Advancement (ADV), Facilities (FAC). Alat ukur ini terdiri dari 40 aitem yang disusun dalam skala likert dengan 5 pilihan jawaban. Semakin tinggi skor rata-rata individu menunjukkan kesejahteraan psikologisnya di tempat kerja semakin tinggi.

Analisi data dilakukan dengan menggunakan dua teknik analisis,yaitu ANOVA satu-arah dan Korelasi Pearson.

\section{Hasil dan Pembahasan}

Setelah melakukan pengumpulan data, peneliti mendapatkan responden sebanyak 72 orang karyawan. Sampel terdiri dari 45 laki-laki dan 27 perempuan. Usia sampel rerata 33,26 tahun. Adapun gambaran tipe kepribadian sampel ditampilkan dalam Tabel 1.

Tabel 1

Data Deskriptif Sampel

\begin{tabular}{lll}
\hline Tipe Kepribadian & $\mathrm{f}$ & $\%$ \\
\hline $\mathrm{D}$ & 11 & 15,3 \\
\hline $\mathrm{I}$ & 8 & 11,1 \\
\hline $\mathrm{S}$ & 35 & 48,6 \\
\hline $\mathrm{C}$ & 16 & 22,2 \\
\hline Tidak diketahui & 2 & 2,8 \\
\hline
\end{tabular}

Berdasarkan tabel tersebut tampak paling banyak sampel memiliki tipe kepribadian yang dominan yaitu S (Steady) diikuti oleh tipe kepribadian C (Compliance). Paling sedikit adalah sampel dengan tipe kepribadian yang dominan I (Influence). Hal ini berarti, rata-rata karyawan memiliki karakteristik suka berorientasi akan hubungan dengan orang lain atau rekan kerja, dengan keluarga (family-oriented), termotivasi oleh keajegan atau situasi yang aman, dan cenderung bekerja dengan fase pelan (Jones \& Hartley, 2013)

Tahap selajutnya peneliti melakukan uji normalitas dengan teknik analisis statistik Kolmogorov-Smirnov pada dua variabel, yaitu LMX $(p=0,813)$ dan EWB $(p=0,284)$. Hasil uji normalitas menunjukkan distribusi data dari kedua variabel ini adalah normal. Hasil uji analisis statistik menggunakan ANOVA satu arah menunjukkan hanya LMX yang ditentukan oleh DISC atasan. Terdapat perbedaan yang signifikan dalam nilai EWB berdasarkan tipe kepribadian atasan. Hasil uji analisis statistik ini terlihat dalam Tabel 2.

Berdasarkan uji post-hoc antara tipe kepribadian atasan dan LMX maka terdapat perbedaan signifikan pada LMX bawahan berdasarkan tipe kepribadian atasan, dimana terdapat rata-rata LMX yang lebih tinggi dan berbeda secara signifikan pada bawahan dibawah kepemimpinan tipe kepribadian $\mathrm{C}(p<.01)$ dan tipe $\mathrm{S} \quad(p<.05)$. Terakhir, peneliti melakukan uji korelasi antara variabel LMX dan EWB. Hasil uji korelasi menunjukkan 
terdapat hubungan yang signifikan antara LMX dan EWB bawahan $(\mathrm{r}=0,417, p<0,01)$. Hasil ini menunjukkan semakin tinggi interaksi antara atasan-bawahan maka bawahan akan makin menunjukkan kesejahteraan psikologis di tempat kerjanya.

Tabel 2

\begin{tabular}{|c|c|c|}
\hline \multicolumn{3}{|c|}{ Hasil Uji ANOVA Satu Arah } \\
\hline & LMX & $P$ \\
\hline $\begin{array}{l}\text { Tipe } \\
\text { kepribadian } \\
\text { atasan }\end{array}$ & 4,874 & $0,006^{*}$ \\
\hline
\end{tabular}

Temuan ini melengkapi hasil penelitian yang dilakukan oleh Harris, Harris, dan Eplion (2007) dimana dalam penelitian tersebut ditemukan bahwa beberapa karakteristik kepribadian atasan seperti locus of control, kebutuhan untuk berkuasa (neef of power), dan self-esteem kesemuanya memiliki kaitan dengan kualitas yang tinggi dalam interaksi atasan bawahan. Tambahan dari penelitian ini untuk melengkapi simpulan penelitian sebelumnya tentang peran karakteristik kepribadian atasan terhadap kualitas interaksi atasan bawahan adalah, terdapat beberapa tipe kepribadian atasan, yaitu atasan dengan karakteristik steady dan conscientious memiliki peran dalam terbentuknya hubungan yang berkualitas antara atasan dan bawahan. Hanya saja apakah locus of control, kebutuhan untuk berkuasa (need of power), dan self-esteem memiliki hubungan dengan tipe kepribadian seseorang memerlukan penelitian lebih lanjut.

Menurut (Lebowitz, 2015), karakteristik kepribadian steady (S) umumnya ditandai dengan karakteristik sabar dan loyal. Karyawan dengan kepribadian S dalam tim kerja akan mengusahakan suasana kerja yang harmonis, berperan menjadi pendengar yang baik, dan menyelesaikan masalah dengan kesepakatan. Kepribadian Conscientious (C) ditandai dengan karakteristik yang sangat peduli dengan kualitas kerja yang baik, menyukai cara kerja yang sistematis, serta menyukai aturan atau prosedur. Menurut Bhardwaj, Mishra, dan Hemalatha (2017), kedua karakteristik ini dikategorikan sebagai tipe pasif, yaitu tipe yang tidak membela dirinya sendiri dan cenderung puas dengan posisi yang dimilikinya saat ini.

Dapat dipahami bahwa hanya kedua karakteristik ini yang memiliki hubungan signifikan dan positif dengan kualitas interaksi atasan bawahan dikarenakan menurut Su'udy (2009), orang Indonesia lebih menyukai gaya kepemimpinan yang suka berkompromi dan mengintegrasikan berbagai kepentingan. Hal tersebut juga diperkuat oleh Mulder (2014) yang mengatakan bahwa karyawan di Indonesia dideskripsikan sebagai individu yang ramah, menyukai perdamaian, serta suka menolong. (Kabasakal \& Bodur, 2004) dalam studi tentang values karyawan di Indonesia, menyatakan bahwa karyawan di Indonesia memiliki values tertinggi pada dimensi orientasi terhadap orang lain dibandingkan dengan karyawan di Negara yang lain. Values ini dicirikan dengan karakteristik memperhatikan orang lain, toleran terhadap kesalahan orang lain, baik hati, dan memiliki sensitivitas kepada orang lain.

Hasil dari penelitian ini juga membawa implikasi positif terhadap teori kepemimpinan berdasarkan trait (trait based leadership theories) yang selama ini dianggap gagal menjelaskan trait kepemimpinan yang efektif untuk berbagai situasi (Guy, 2007). 
Hasil penelitian ini, menunjukkan bahwa ciri pemimpin yang sistematis dan memiliki emosi stabil memiliki peran dalam terbentuknya kualitas interaksi yang baik antara atasan bawahan. Adanya kualitas interaksi atasan bawahan yang baik pada akhirnya meningkatkan kesejahteraan psikologis karyawan di tempat kerja.

\section{Simpulan}

Berdasarkan penelitian yang telah dilakukan, dapat disimpulkan bahwa terdapat hubungan antara tipe kepribadian atasan dan kualitas hubungan atasan bawahan, serta terdapat hubungan antara kualitas interaksi atasan-bawahan dengan kesejahteraan psikologis karyawan. Hasil penelitian ini masih memiliki kekurangan karena penelitian tidak memfokuskan pada kelompok demografi pekerja secara spesifik, khususnya pada kelompok pekerja yang karakteristik pekerjaannya beresiko tinggi, sehingga untuk penelitian selanjutnya dapat mempertimbangkan dilakukan pada kelompok demografi pekerja dengan karakteristik yang lebih spesifik.

\section{Daftar Pustaka}

Badeni. (2013). Kepemimpinan dan Perilaku Organisasi. Bandung: Alfabeta.

Bhardwaj, C. A., Mishra, M., \& Hemalatha, S. (2017). An Automated Compatibility Prediction Engine using DISC Theory Based Classification and Neural Networks. International Journal of Engineering, Technology, Science and Research, 4(8).

Goni, C. K. E., Opod, H., \& David, L. (2016). Gambaran Kepribadian Berdasarkan Tes DISC Mahasiswa Fakultas Kedokteran Universitas Sam Ratulangi Manado. Jurnal E-Biomedik (eBm), 4(2).

Graen, G. B. (1976). Role making processes within complex organizations. In D. Dunnette, Marvin (Ed.), Handbook of Industrial and Organizational Psychology (pp. 12011245). Chicago: Rand-McNally.

Graen, G. B., \& Uhl-Bien, M. (1995). Relationship-based approach to leadership: Development of leader-member exchange (LMX) theory of leadership over 25 years: Applying a multi-level multa-domain perspective. Management Departement Faculty Publications, (Lmx), 219-247. https://doi.org/10.1016/10489843(95)90036-5

Guy, P. N. (2007). Leadership : theory and practice (4th ed.). Thousand Oaks, CA: Sage Publications.

Harris, K. J., Harris, R. B., \& Eplion, D. M. (2007). Personality, Leader-Member Exchanges, and Work Outcomes. Journal of Behavioral \& Applied Management, $8(2), 92-107$.

Jones, C. S., \& Hartley, N. T. (2013). Comparing Correlations Between Four-Quadrant 
And Five-Factor Personality Assessments. American Journal of Business Education (Online), 6(4), 459.

Juniper, B. (2010). Evaluation of a novel approach to measuring well-being in the workplace.

Kabasakal, H., \& Bodur, M. (2004). Humane Orientation in Societies, Organizations, and Leader Attributes. In R. J. House, P. J. Hanges, M. Javidan, P. W. Dorfman, \& V. Gupta (Eds.), Culture, Leadership, and Organizations: The GLOBE Study of 62 Societies (pp. 564-595). Thousand Oaks, CA: Sage Publications.

Karasek, R. A. (1979). Job demands, job decision latitude, and mental strain: Implications for job redesign. Administrative Science Quarterly, 24, 285-308.

Lebowitz, S. (2015). A psychologist says these personality types are most likely to clash at work.

Lestari, A. A. (2017). Hubungan Antara Keseimbangan Kehidupan-Kerja dengan Kesejahteraan Psikologis pada Ibu Bekerja di Institusi Pemerintahan Jogjakarta. Universitas Islam Negeri Sunan Kalijaga: Jogjakarta.

Liden, R. C., \& Maslyn, J. M. (1998). Multidimensionality of Leader-Member Exchange: An Empirical Assessment through Scale Development. Journal of Management. https://doi.org/10.1177/014920639802400105

Marston, W. M. (1928). Emotions of normal people. International Library of Psychology and Philosophy and Scientific Method. https://doi.org/10.1037/13390-000

Maslyn, J. M., \& Uhl-Bien, M. (2001). Leader-member exchange and its dimensions: Effects of self-effort and other's effort on relationship quality. Journal of Applied Psychology. https://doi.org/10.1037//0021-9010.86.4.697

Mulder, N. (2014). The Ideology of Javanese-Indonesian Leadership. In H. Antlov \& S. Cederroth (Eds.), Leadership on Java: Gentle Hints, Authoritarian Rule. New York: Routledge.

Nastiti, A. (2015). Hubungan Dominance dan Influence pada Alat Tes DISC dengan Minat Wirausaha pada Mahasiswa. Fakultas Psikologi. Unika Soegijatpranata.

Orsila, R., Luukkaala, T., Luukkaala, T., Manka, M. L., \& Nygard, C. H. (2011). A new approach to measuring work-related well-being. International Journal of Occupational Safety and Ergonomics. https://doi.org/10.1080/10803548.2011.11076900

Ping, F. S., \& Yue, H. K. (2010). The mediating effects of leader-member exchange (LMX) and tema-member exchange (TMX) on the relationship between emotional intelligence, job satisfaction and job performance of employees. An Honours Degree Project Hong Kong Baptist University, Hong Kong, (April).

Siegrist, J. (2012). Effort-reward imbalance at work - theory, measurement and evidence. Department of Medical Sociology, University Düsseldorf, Düsseldorf. 
SIOP. (1998). Leader-Member Exchange (LMX) Theory.

Su'udy, R. (2009). Conflict Management Styles of Americans and Indonesians: Exploring the Effects of Gender and Collectivism/Individualism. Communication Studies. University of Kansas.

Tanuwijaya, F. M., \& Kurniadi, A. C. (2007). Pengaruh komunikasi atasan-bawahan dan motivasi kerja terhadap kinerja karyawan bagian marketing di PT. Bank Danamon Indonesia, Tbk. kantor wilayah Surabaya. Petra Christian University.

The JakartaPost. (2012). Survey shows Indonesians worry about work-life balance.

Utami, A. B., \& Pratitis, N. T. (2013). Peran Kreativitas Dalam Membentuk Strategi Coping Mahasiswa Ditinjau Dari Tipe Kepribadian Dan Gaya Belajar. Persona, Jurnal Psikologi Indonesia, 2(3), 232-247. 